\title{
DAMPAK TAX ACCOUNTING CHOICES TERHADAP TAX AGGRESSIVE
}

\author{
Harnovinsah dan Septyana Mubarakah \\ Fakultas Ekonomi dan Bisnis Universitas Mercu Buana, Jakarta dan \\ Magister Akuntansi Universitas Mercu Buana Jakarta \\ Email:dr.harnovinsah@gmail.com;dan septyanamubarakah@gmail.com
}

\begin{abstract}
Tax Accounting choices in this study chose the straight-line method and the FIFO method,which is the management actions in determining the policies that are applied to compile financial statements and used as an indicator of tax aggresivitas. In addition the study also used the deffered tax expense and firm size as another independent variable to measure the tax aggresivitas action of the tax aggressiveness. This study aims to analyze the tax accounting choices, defferen tax expense and tax firm size as an indicator of tax aggressiveness. The samples used in this study as many as 50 manufacturing companies listed on the Indonesia Stock Exchange (IDX) during the period 2010-2014. The sample were with how purposive random sampling by using certain criteria. Tax accounting choices is measured by the selection of the method of straight line method and the FIFO method with dummy variables, whereas for deffered tax expense is measured by comparing the deffred tax expense by total assets. Firm size is measured by taking the natural logarithm of total assets. The results of this study found that the straightline method significant negative effect against the tax aggressiveness. while the FIFO method has no affect against tax aggressiveness. Deffered tax expense significant negative effect on tax aggressiveness and firm size are significant negative effect against tax aggressiveness. So it can be said that the method of straight-line and deffered tax expense can be used as an indicators of tax aggressiveness.
\end{abstract}

Keywords: Tax accounting choices, tax aggressiveness, Deffered Tax Expense, Firm Size

Abstrak. Penelitian ini bertujuan untuk menganalisis tax accounting choices, defferen tax expense dan firm size sebagai indikator tax aggressiveness. Sampel yang digunakan penelitian ini sebanyak 50 perusahaan manufaktur yang terdaftar di Bursa Efek Indionesia (BEI) selama periode 2010-2014. Sampel diambil dengan cara purposive random sampling dengan menggunakan criteria tertentu. Tax accounting choices diukur dengan pemilihan metode garis lurus dan metode FIFO dengan variabel dummy, sedangkan untuk deffered tax expense diukur dengan membandingkan deffred tax expense dengan total asset.Firm size diukur dengan melakukan logaritma natural total asset. Hasil penelitian ini menemukan bahwa metode garis lurus berpengaruh signifikan negative terhadap tax aggressiveness sedangkan metode FIFO tidak berpengaruh terhadap tax aggressiveness. Deffered tax expense berpengaruh signifikan negative terhadap tax aggressiveness dan firm size berpengaruh signifikan negative terhadap tax aggressiveness. Sehingga dapat dikatakan bahwa metode garis lurus dan deffered tax expense dapat dijadikan sebagai indikator tax aggressiveness

Kata kunci: Tax accounting choices, tax aggressiveness, Deffered Tax Expense, Firm Size 


\section{PENDAHULUAN}

Isu penghindaran pajak merupakan masalah yang lazim di setiap Negara masyarakat selalu mencoba untuk melakukan penghindaran pajak melalui kelemahan yang ada dalam peraturan perpajakaan yang ada di setiap negara ( Andreoni et al , 1998;Uadiale et al, 2010; Verboon dan Dijke , 2007). Tindakan Perusahaan yang ditujukan untuk menurunkan laba kena pajak dengan perencanaan pajak, baik dengan cara yang tergolong maupun tidak tergolong tax evasion menurut Frank et al (2009) merupakan tindakan pajak agresif atau agresivitas pajak. Tindakan pajak agresif tidak selalu berawal dari perilaku ketidakpatuhan terhadap peraturan perpajakan, tapi juga dari penghematan pajak yang dilakukan sesuai dengan peraturan. Semakin perusahaan memanfaatkan celah peraturan untuk menghemat beban pajak maka perusahaan dianggap telah melakukan agresivitas pajak meskipun tindakan tersebut tidak menyalahi peraturan yang ada (Desai and Dharmapala,2008; Hanlon dan Heitzman,2010; Rego and Wilson , 2012).

Tindakan pajak agresif tidak hanya berasal dari ketidakpatuhan terhadap peraturan perpajakan namun dapat berasal dari aktivitas penghematan yang sesuai dengan peraturan yang berlaku sehingga sering kali agresivitas pajak disebut juga sebagai tax sheltering atau tax avoidance. Pajak agresif dapat berbentuk apapun selama beban pajak perusahaan menjadi lebih rendah dari yang seharusnya Hartadinata dan Shauki (2012) mengutip pendapat Frank et al (2009) yang mendefinikan Tax aggressiveness sebagai sebuah tindakan yang ditunjukan untuk menurunkan taxable income perusahaan dengan melalui metode - metode tax planning baik yang diklasifikan sebagai tax evasion maupun yang tidak. Selain perubahan tarif pajak ada hal lain yaitu signifikannya beban pajak yang ditanggung oleh perusahaan dan pemiliknya (pemegang saham), dapat diduga pemegang saham menginginkan penghindaran pajak (Chen et al, 2010). Perusahaan menghindari pajak dengan memanfaatkan regulasi yang tidak jelas untuk memperoleh outcome pajak yang menguntungkannya (Dyreng et al, 2008 ).

Hartadinata dan Shauki (2012) yang menyatakan peningkatan managerial ownership menunjukan semakin tinggi tax aggressivitas nya, sementara peningkatan debt financing dari leverage policy memicu penurunan tingkat agresivitas pajak. Tindakan berdasarkan penelitian tersebut dapat dijadikan dasar bahwa aggressivitas dipengaruhi oleh para manajemen dengan metode kebijakan yang menjadi pilihan dalam penyusunan laporan keungan perusahaan. Pemilihan kebijakan akuntansi (accounting choices) sarana bagi manajemen untuk melakukan tax aggressiveness. Hassan (2012), yang menyebutkan bahwa riset tentang accounting choices yang dimotivasi dan didasari oleh aspek pajak (tax - base - motivation) pada umumnya berkaitan dengan perubahan tarif pajak. Seperti diketahui antara rentang waktu tahun 2010 sampai dengan 2014 terdapat penurunan tarif pajak dengan diterapkannya tarif tunggal, hal ini menjadi salah satu alasan dalam penelitian ini selain itu pemilihan kebijakan akuntansi dalam pemilihan metode penyusutan untuk aktiva tetap akan menyebabkan terjadinya perbedaan nilai aktiva tetap, dimana akan menimbulkan deferred tax assets (pajak tangguhan ). Penelitian Meiza (2013) defereed tax expense berpengaruh negatif signifikan terhadap tax avoidance hal ini konsisten dengan penelitian Philips (2002) yang menyatakan bahwa deferred tax expense secara signifikan lebih akurat dari ukuran akrual lainnya untuk mendeteksi perusahaan yang menghindari kerugian (avoiding loss). Penelitian yang dilakukan Khoiru Rusidy (2012) menunjukkan bahwa ukuran perusahaan tidak berpengaruh terhadap tax avoidance di Indonesia, yang artinya bahwa perilaku perusahaan-perusahaan di Indonesia untuk 
semakin melakukan aggressive tax avoidance tidak di pengaruhi besar kecilnya perusahaan. Zimmerman, (1983) menunjukkan adanya hubungan positif antara ukuran perusahaan dengan aggressive tax avoidance, demikian pula dengan Richardson dan Lanis (2013). Fenomena kasus aggressive tax di Indonesia maupun adanya perbedaan hasil penelitian (research GAAP) inilah yang memotivasi penelitian untuk melakukan uji empiris ukuran perusahaan dengan aggressive tax. Hasan (2012) yang mengatakan pajak merupakan satu beban yang harus dikelola untuk tujuan efisiensi, hal ini akan tercapai dengan melakukan pemilihan kebijakan metode akuntansi yang akan menurunkan taxable income. Dengan turunnya taxable income maka akan menurunkan beban pajak yang ditanggung perusahaan, hal ini akan dilakukan untuk memenuhi kepentingan manajemen dan pemegang saham.

Berdasarkan penjelasan dan uraian penelitian-penelitian yang telah dilakukan di beberapa Negara, tindakan aggresivitas pajak ini membuktikan keterkaitan antara kepentingan manajemen dengan kebijakan metode akuntansi . Jika hal ini dihubungkan dengan literatur teori akuntansi positive dan agency teori. Dimana teori tersebut mengungkapkan apa yang menjadi perilaku manusia dengan keinginan dan kepentingan dari pribadi manusia dalam hal ini manajemen dan para pemegang saham.Jika pada penelitian sebelumnya perubahan tarif pajak dijadikan dasar penilaian tax aggressive, berbeda dengan penelitian ini selain dari perubahan tarif pajak penelitian ini juga menilai kebijakan akuntansi yang dipilih manajemen sebagai indikator tax aggressive, yaitu pada pemilihan metode depresiasi yang dilakukan perusahan dan metode pencatatan inventory serta perubahan temporer yang terefleksi pada kenaikan atau penurunan aktiva dan kewajiban pajak tangguhan harus diperlakukan sebagai beban pajak tangguhan (deferred tax expenses) atau penghasilan pajak tangguhan (deferred tax income) dan dilaporkan dalam laporan laba-rugi tahun berjalan bersama-sama beban pajak kini (current tax expenses.) Tujuan dari penelitian ini adalah untuk melihat pengaruh kebijakan akuntansi (Tax Accounting Choices) sebagai indikator Tax Aggressiveness

\section{KAJIAN TEORI}

Teori Akuntansi Positif. Watts dan Zimmerman (1986) dalam Teori akuntansi positif (TAP) secara jelas berupaya untuk menjelaskan tentang kebijakan akuntansi menjadi suatu masalah bagi perusahaan dan Stakeholder terkait dengan laporan keuangan, dalam memilih kebijakan akuntansi yang hendak dipilih oleh perusahaan dalam kondisi tertentu. Teori akuntansi positif didasarkan pada pandangan bahwa perusahaan merupakan suatu 'nexus of contracts'. Artinya, perusahaan merupakan suatu entitas yang terdiri dari berbagai kontrak yang datang padanya. Misalnya, kontrak dengan agent (manajer), karyawan , pemasok, dan dengan pemberi modal serta pihak yang berkepentingan lainnya termasuk di dalamnya adalah pemerintah sebagai pemungut pajak. Sebagai suatu entitas yeng terdiri dari berbagai kontrak, jelas secara rasional perusahaan akan berusaha meminimalkan contracting cost yang berkaitan dengan kontrak-kontrak yang masuk padanya. Beberapa dari kontrak tersebut pasti akan melibatkan kebijakan-kebijakan akuntansi, dan teori akuntansi positif berargumentasi bahwa perusahaan sebagai entitas akan selalu berusaha untuk memanfaatkan kebijakan akuntansi tersebut guna meminimalisir contracting cost. Hal ini diperkuat dengan fleksibilitas yang tinggi yang dimungkinkan oleh lembaga profesi sebagai penyusun standar akuntansi kepada manajemen untuk memilih dari seperangkat kebijakan akuntansi yang diperkenankan. 
Teori akuntansi positif menggunakan agency theory untuk menjelaskan dan memprediksi pilihan kebijakan akuntansi oleh manajer. Teori akuntansi positif yang diformulasikan oleh Watts dan Zimmerman (1986) dan menurut mereka ada tiga hipotesis yang mendorong perusahaan untuk melakukan earnings management, yaitu: (a) The bonus plan hypothesis. Manajer sebagai agent perusahaan cenderung untuk memilih prosedur akuntansi yang menggeser reported earnings dari future period ke current period (menaikkan laba yang dilaporkan sekarang), untuk mendapatkan bonus; (b) The debt covenant hypothesis. Perusahaan akan memilih prosedur akuntansi yang menggeser reported earnings dari future periods ke current period (menaikkan laba yang dilaporkan sekarang) apabila dalam kondisi yang semakin mendekati pelanggaran debt covenant (perjanjian kontrak hutang); (c) The political cost hypothesis. Besarnya political cost yang dihadapi suatu perusahaan, maka manajer akan cenderung untuk memilih kebijakan akuntansi yang menangguhkan reported earnings dari current ke future period (menurunkan laba yang dilaporkan sekarang)

Tax Aggressive. Dalam pandangan kontemporer agresivitas pajak mempunyai dua tujuan, yakni tidak hanya menutup-nutupi pendapatan dari otoritas pajak, tapi juga menutupnutupi aktivitas tersembunyi yang dapat merugikan pemilik atau pemegang saham. Sebagai agent, manajer secara moral bertanggung jawab untuk mengoptimalkan keuntungan para pemilik (principal), namun disisi lain manajer mempunyai kepentingan memaksimumkan kesejahteraan mereka (Jensen dan Meckling, 1976) Agent sebagai pihak yang lebih tahu pengelolaan perusahaan maka akan menerapkan kebijakan-kebijakan akuntansi yang dapat mendukung kepentingannya. Untuk melihat suatu perusahaan melakukan penghindaran pajak atau tidak maka dapat dilihat dari penerapan penilaian persediaan, metode yang yang diterapkan sesuai dengan peraturan perpajakan yaitu metode FIFO jika diluar aturan tersebut laba yang dihasilkan akan menurun, dengan menurunnya laba maka menunjukan kebijakan akuntansi yang dipilih manajemen memiliki tujuan untuk tertentu seperti halnya agresivitas pajak. Selain itu juga dalam penelitian ini mengukur dengan penerapan metode penyusutan untuk aktiva tetap apa sudah sesuai dengan metode garis lurus yang diterapkan untuk pelaporan pajak. Pemilihan metode kebijakan akuntansi untuk metode penilaian persediaan dan penyusutan pada penelitian ini mengacu pada penelitian Gopalakrishnan (1994), dengan menyatakan bahwa menunjukkan bahwa unlevered firms cenderung untuk memilih income accounting increasing method dengan melakukan pemilihan metode persediaan. Sedangkan untuk perusahaan perusahaan kecil memilih biaya rendah dengan mengadopsi metode akuntansi penyusutan garis lurus, dan leverage berpengaruh positif pada pemilihan metode persediaan tapi berpengaruh negative terhadap metode penyusutan.

Mengingat pajak adalah beban (yang akan mengurangi laba bersih perusahaan) maka perusahaan akan berupaya semaksimal mungkin agar dapat membayar pajak sekecil mungkin dan berupaya untuk menghindari pajak. Namun demikian penghindaran pajak harus dilakukan dengan cara-cara yang legal agar tidak merugikan perusahaan dikemudian hari. Plesko (2002) dan Phillips et al. (2003) mengungkapkan bahwa semakin besar perbedaan antara laba fiskal dengan laba akuntansi menunjukkan semakin besarnya diskresi manajemen. Besarnya diskresi manajemen tersebut akan terefleksikan dalam beban pajak tangguhan dan mampu digunakan untuk mendeteksi praktik manajemen laba pada perusahaan. Dihubungkan dengan teori akuntansi positif Watts dan Zimmerman (1990) menyatakan bahwa perilaku manusia bisa dijelaskan dengan perilaku berupa 
keinginan meningkatkan kesejahteraan diri sendiri, dan naluri untuk mengarahkan pada pemahaman dan prediksi dalam menetukan pilihan kebijakan akutansi perusahaan dinyatakan sebagai bagian dari kebutuhan perusahaan untuk meminimalisir biaya kontraknya. Kebijakan akuntansi sangat ditentukan oleh struktur organisasi perusahaan menurut kondisi lingkungannya dan pilihan kebijakan akuntansi menjadi bagian dari pengelolaan perusahaan. Lingkungan perusahaan yang semakin besar, kebijakan akuntansi yang dipilih untuk memenuhi kepentingan manajemen dan stakeholders semakin besar dan luas. Dalam praktiknya kebijakan akuntansi akrual diterapkan lewat perlakuan transaksi yang berkaitan dengan laba agar lebih mendekati nilai ekspektasi perusahaan. Hal ini mengingat pihak manajemen memiliki kompetensi untuk mengendalikan kuantifikasi kejadian yang berpengaruh terhadap laba. Kebijakan akuntansi berpotensi dalam mempengaruhi keputusan riil manajemen, termasuk keputusan untuk mengintervensi suatu standar akuntansi. Zeff (1978) mendefinisikan konsekuensi ekonomi sebagai dampak pelaporan akuntansi dalam perilaku pengambilan keputusan bisnis, pemerintahan (dalam penentuan jumlah pajak) dan kreditur. Esensi dari definisi ini adalah laporan akuntansi dapat mempengaruhi keputusan riil yang dibuat manajer dan mencerminkan keinginannya. Sehingga semakin perusahaan tersebut besar kemungkinan untuk melakukan tax aggressiveness lebih tinggi. Menurut politik ekonomi, akuntansi secara eksplisit menyatakan bahwa alternatif sistem pelaporan keuangan (misalnya antara yang diregulasi melawan yang tidak) memiliki konsekuensi sosial, yaitu dalam suatu sistem beberapa orang akan merasa lebih baik saat yang lain merasakan sebaliknya, sehingga sistem seperti terpolitisasi sebagai suatu perilaku ekonomi.

Pengaruh Accounting choices terhadap tax aggressiveness. Perkembangan metode metode akuntansi memberikan kesempatan para manajer untuk memilih kebijakan kebijakan akuntansi yang dapat mendukung kepentingan stakeholders dan manajemen. Dalam penelitian ini memilih Descreasing earnings method (Metode penurunan laba) yaitu dengan menerapkan metode penilaian persediaan dan metode penyusutan aktiva tetap sejalan dengan penelitian Gopalakrishnan (1994), dengan menyatakan bahwa menunjukkan bahwa unlevered firms cenderung untuk memilih income accounting increasing method dengan melakukan pemilihan metode persediaan. Sedangkan untuk perusahaan perusahaan kecil memilih biaya rendah dengan mengadopsi metode akuntansi penyusutan garis lurus dan leverage berpengaruh positif pada pemilihan metode persediaan tapi berpengaruh negative terhadap metode penyusutan.

Kebijakan akuntansi berpotensi dalam mempengaruhi keputusan riil manajemen, termasuk keputusan untuk mengintervensi suatu standar akuntansi. Zeff (1978) mendefinisikan konsekuensi ekonomi sebagai dampak pelaporan akuntansi dalam perilaku pengambilan keputusan bisnis, pemerintahan (dalam penentuan jumlah pajak) dan kreditur. Esensi dari definisi ini adalah laporan akuntansi dapat mempengaruhi keputusan riil yang dibuat manajer dan mencerminkan keinginannya. Pernyataan ini didukung dengan penelitian Hartadinata dan Shauki (2012) yang menyatakan bahwa jika managerial ownership yang meningkat akan meningkatkan tindakan aggressive tax ini sejalan juga dengan penelitian Sabrina dan Martani (2014) perusahaan keluarga lebih menghidari pajak dan Aminu (2012) perusahaaan dengan ukuran yang lebih besar dan tinggi tingkat konsentrasi kepemilikan cenderung memilih pendapatan menurun ini untuk melakukan efisiensi sehingga memaksimalkan nilai perusahaan. 
Jumlah dari biaya penyusutan aktiva tetap dan penilaian persediaan sangat tergantung pada metode yang dipilih manajemen perusahaan, oleh karena itu pemilihan metode penyusutan dan penilaian persediaan haruslah tepat karena akan mempengaruhi besarnya laba perusahaan. Naik turunnya laba perusahaan di setiap periode tergantung dari pemilihan metode akuntansi yang diterapkan manajemen. Hal ini membuktikan jika kebijakan akuntansi berpengaruh pada penghindaran pajak, dengan begitu dapat dirumuskan dengan hipotesa sebagai berikut:

H1: Tax Accounting Choices berpengaruh terhadap Tax Aggressiveness.

Pengaruh Deffered tax Expense terhadap Tax Aggressiveness. Berdasarkan PSAK no. 46 alokasi pajak antar periode diawali dengan adanya keharusan bagi perusahaan untuk mengakui aktiva dan kewajiban pajak tangguhan yang harus di laporkan di neraca.Pengakuan aktiva dan kewajiban pajak tangguhan tersebut merupakan pengakuan tentang konsekuensi pajak dimasa mendatang atas efek kumulatif perbedaan temporer pengakuan penghasilan dan beban untuk tujuan akuntansi dan tujuan fiskal. Dalam pendekatan aktiva-kewajiban, yang dimaksud dengan perbedaan temporer adalah perbedaan antara dasar pengenaan pajak (DPP) dari suatu aktiva atau kewajiban dengan nilai tercatat aktiva atau kewajiban tersebut.

Efek perubahan temporer yang terefleksi pada kenaikan atau penurunan aktiva dan kewajiban pajak tangguhan harus diperlakukan sebagai beban pajak tangguhan (deferred tax expenses) atau penghasilan pajak tangguhan (deferred tax income) dan dilaporkan dalam laporan laba-rugi tahun berjalan bersama-sama beban pajak kini (current tax expenses), dengan penyajian secara terpisah. Dengan demikian, berdasarkan PSAK no.46 $\mathrm{PPh}$ yang dilaporkan dalam laporan laba-rugi akan menunjukkan beban pajak kini ditambah beban pajak tangguhan, atau beban pajak kini dikurangi penghasilan pajak tangguhan. Jumlah agregat beban pajak kini dan pajak tangguhan dapat berupa beban pajak (tax expenses) atau penghasilan pajak (tax income). Pajak adalah beban bagi perusahaan, sehingga wajar jika tidak satupun perusahaan (wajib pajak) yang dengan senang hati dan suka rela membayar pajak. Karena pajak adalah iuran yang sifatnya dipaksakan, maka negara juga tidak membutuhkan 'kerelaan wajib pajak'. Yang dibutuhkan oleh Negara adalah ketaatan. Suka tidak suka, rela tidak rela, yang penting bagi negara adalah perusahaan tersebut telah membayar pajak sesuai dengan ketentuan yang berlaku. Lain halnya dengan sumbangan, infak maupun zakat, kesadaran dan kerelaan pembayar diperlukan dalam hal ini. Mengingat pajak adalah beban (yang akan mengurangi laba bersih perusahaan) maka perusahaan akan berupaya semaksimal mungkin agar dapat membayar pajak sekecil mungkin dan berupaya untuk menghindari pajak. Namun demikian penghindaran pajak harus dilakukan dengan cara-cara yang legal agar tidak merugikan perusahaan di kemudian hari. Plesko (2002) dan Phillips et al. (2003) mengungkapkan bahwa semakin besar perbedaan antara laba fiskal dengan laba akuntansi menunjukkan semakin besarnya diskresi manajemen. Besarnya diskresi manajemen tersebut akan terefleksikan dalam beban pajak tangguhan dan mampu digunakan untuk mendeteksi praktik tax aggressiveness pada perusahaan. Jadi dapat disimpulkan semakin tinggi pelaporan pajak tangguhan atau beban pajak ditunda perusahaan yang diukur dengan alokasi pajak antar periode akan mempengaruhi penghindaran pajak perusahaan, semakin tinggi alokasi antar periode berarti semakin kecil praktik tax aggressiveness yang dilakukan perusahaan. Hassan (2012) mengutip Dhaliwal dan Wang (1992) melaporkan bukti bahwa perusahaan melakukan penyesuaian angkaangka akuntansi dengan menggeser perbedaan tetap dan perbedaan waktu pada beberapa 
periode untuk meminimalkan dampak pajak. Ini sejalan dengan penelitian yang dilakuakan Meiza (2013) yang menyatakan Deffered tax expense berpengaruh negative terhadap tax avoidance. Sehingga dapat dirumuskan hipotesis sebagai berikut:

H2: Semakin tinggi Deferred tax expense maka Tax Aggressiveness semakin rendah.

Pengaruh Firm size terhadap Tax Aggressiveness. Pengembangan dugaan ini merujuk pada beberapa penelitian sebelumnya, penelitian Siegfried (1977) menunjukkan hubungan negatif antara ukuran perusahaan, dimana perusahaan besar cenderung melakukan manipulasi pajak karena perusahaan besar menginginkan laba yang besar dan memiliki kekuatan politik yang lebih dibandingkan perusahaan kecil dan mampu untuk mengurangi beban pajak yang dikenakan, hal ini juga dengan sejalan penelitian Rego (2003), Hanlon (2005), Derashid et al. (2003), Kim dan Limpaphayom, (1998), mereka menyimpulkan bahwa semakin besar perusahaan maka efektif tax rate (ETR) semakin kecil, data tersebut menunjukkan semakin meningkatnya tindakan aggressive tax. Hal ini sejalan dengan penelitian Darmawan dan Sukarta (2014) namun berbeda juga dengan penelitian Rusydi (2013) dengan yang menyatakan bahwa perusahaan yang melakukan tax aggressive tidak melihat ukuran perusahaan besar atau kecil.

Perbedaan hasil dari penelitian terdahulu yang tidak konsisten maka menjadi alasan penelitian ini dilakukan, demikian juga halnya dengan fenomena yang terjadi di Indonesia, berdasarkan kasus perpajakan yang di tangani oleh DJP, berdasarkan beberapa hasil penelitian diatas dan fenomena kasus perpajakan di Indonesia, terdapat suatu benang merah yang menjadi kesimpulan sementara dalam penelitian yaitu semakin besar perusahaan, maka semakin meningkatnya tindakan aggressive tax, sehingga penulis menyusun dugaan sebagai berikut:

H3: Semakin besar Firm Size maka Tax Aggressiveness semakin tinggi.

\section{METODE}

Defenisi Operasional dan Pengukuran Variabel. Berdasarkan rumusan masalah dan hipotesis yang telah dipaparkan di atas, maka yang menjadi variabel dalam penelitian ini adalah Variabel independen dalam penelitian ini adalah Metode penyusutan Garis Lurus, Metode penilaian persediaan, dan deffered tax expense. Variabel Dependen dalam penelitian ini adalah Agresivitas pajak.

Tax Aggressiveness, dengan ETR digunakan pengukuran karena dianggap dapat merefleksikan perbedaan tetap antara perhitungan laba buku dengan laba fiskal Frank et al. (2009). Sedangkan CETR digunakan karena diharapkan dapat mengidentifikasi keagresifan perencanaan pajak perusahaan yang dilakukan menggunakan perbedaan tetap maupun perbedaan temporer Chen et al. (2010) dihitung sebagai berikut

\section{Current ETR = Current tax expense i,t X 100\% Pretax Income i,t}

Pemilihan kebijakan akuntansi (Accounting Choices) yang diterapkan merupakan variabel independen dalam penelitian. Kebijakan akuntansi dalam penelitian ini menggunakan pengukuran penerapan metode penyusutan yang digunakan, selain itu juga menggunakan kebijakan penerapan penilaian persediaan. Berdasarkan peraturan perpajakan metode untuk penilaian persediaan adalah metode FIFO (First in first out) maka laba yang 
dilaporkan lebih tinggi daripada jika melakukan penilaian persediaan diluar dari FIFO maka bisa dikategorikan perusahaan melakukan tindakan Aggressive pajak. Sedangkan untuk metode Penyusutan (Depresiation) peraturan perpajakan menggunakan metode garis lurus, dimana jika diluar metode garis lurus maka bisa jadi perusahaan dikategorikan aggressive terhadap pajak karena dengan melakukan metode penyusutan di luar garis lurus akan memiliki laba yang lebih rendah. Dalam penelitian ini dilakukan metode dummy, seperti dalam penelitian Gopalakrishnan (1994) yang dilakukan sebelumnya, dengan rumusan berikut ini:

Tabel 1. Pemilihan Kebijakan Akuntansi (Accounting Choices)

\begin{tabular}{lll}
\hline Metode & & \\
\hline Penyusutan & Garis lurus $=0$ & Selain Garis lurus $=1$ \\
Penilaian Persediaan & FIFO $=0$ & Selain FIFO $=1$ \\
\hline
\end{tabular}

Deferred tax expense adalah kenaikan saldo liabilitas pajak yang ditangguhkan dari awal hingga akhir periode akuntansi Kieso (2010). Beban pajak tangguhan adalah beban yang timbul akibat perbedaan temporer antara laba akuntansi dengan laba fiscal Philips et al. (2003 ). Pengukuran deffered tax Asset dalam penelitian ini dengan rumusan berikut:

\section{Deffered Tax Expense i t : Deffered Tax Expense i $t$ Total Asset i(t-1)}

Siegfried (1977) menunjukkan hubungan negatif antara ukuran perusahaan, dimana perusahaan besar cenderung melakukan manipulasi pajak karena perusahaan besar menginginkan laba dan kekuatan politik yang lebih dibandingkan perusahaan kecil dan mampu untuk mengurangi beban pajak yang dikenakan. Firm size Watts dan Zimmerman (1990) dihitung dengan menggunakan natural log total asset perusahaan karena asset dinilai lebih stabil, berikut dibawah ini:

\section{SIZEit $=$ Ln Total Asets it}

Variabel Kontrol adalah variabel yang dikendalikan / dibuat konstan sehingga pengaruh variabel Independen/ variabel bebas terhadap variabel dependen/ variabel tergantung, tidak dapat dipengaruhi oleh faktor luar yang tidak diteliti. Jika akan melakukan penelitian yang sifatnya perbandingan/ komparatif biasanya peneliti menggunakan variabel kontrol. Variabel kontrol yang digunakan dalam penelitian ini Leverage menggambarkan proporsi total utang perusahaan terhadap total aset yang dimiliki perusahaan dengan tujuan untuk mengetahui keputusan pendanaan yang dilakukan oleh perusahaan tersebut. Leverage dihitung dengan total liabilitas dibagi dengan total aset.

$$
\text { LEVit }=\frac{\text { Total Liabilitas it }}{\text { Total Ekuitas }}
$$


Populasi yang digunakan dalam penelitian ini perusahaan Manufaktur yang terdaftar di Bursa Efek Indonesia dari tahun 2010 - 2014. Dalam penelitian ini sampel yang diambil perusahaan Manufaktur berjumlah sebanyak 141 perusahaan. Dipilih perusahaan Manufaktur dengan alasan perusahaan Manufaktur miliki jumlah yang lebih banyak dalam Bursa Efek Indonesia dan mempunyai pengaruh/dampak terhadap pemenuhan pajak yang lebih besar, dan rata - rata manufaktur di Indonesia memiliki laba yang tidak sedikit dari aktivitas yang dilakukan perusahaan. Pemilihan sampel dilakukan dengan menggunakan metode purposive sampling dengan tujuan untuk mendapatkan sampel yang representatif sesuai dengan kriteria dapat dilihat pada Tabel 2.

Tabel 2. Seleksi Sampel

\begin{tabular}{lc}
\hline \multicolumn{1}{c}{ Kriteria Seleksi Sampel } & Jumlah \\
\hline Perusahaan Manufaktur yang terdaftar Di BEI pada tahun 2010 - & 142 \\
2014 & $(20)$ \\
$\begin{array}{l}\text { Perusahaan Baru IPO dan delisting } \\
\text { Perusahaan yang tidak menyampaikan annual reportnya secara terus }\end{array}$ & $(22)$ \\
menerus & $(43)$ \\
Perusahaan yang tidak menyajikan laba positif secara terus menerus & $(5)$ \\
Perusahaan yang tidak menyajikan deffered tax expense & $(2)$ \\
$\begin{array}{l}\text { Perusahaan yang tidak menyajikan informasi metode penyusutan } \\
\text { dan penilaian persediaan }\end{array}$ & 50 \\
Jumlah data yang digunakan dalam penelitian & 250 \\
\hline
\end{tabular}

Metode Analisis. Teknik analisis data yang digunakan adalah Analisis Regresi Berganda yang sebelumnya harus melalui Uji Asumsi Klasik meliputi Uji Normalitas, Uji Multikolinearitas, Uji Heteroskedastisitas, dan Uji Autokorelasi agar data dianggap layak dilanjutkan menuju analisis regresi linear berganda. Berikut ini model analisis regresi linier berganda dalam penelitian:

$$
\mathrm{TAG}=\alpha+\beta 1 \mathrm{DTE}+\beta 2 \mathrm{GL}+\beta 3 \mathrm{FIFO}+\beta 4 \mathrm{SIZE}+\beta 5 \mathrm{LEV}+\mathrm{e}
$$

Hasil Pengujian dan Pembahasan. Hasil Uji Asumsi Klasik yang meliputi Uji Normalitas, Uji Multikolinearitas, Uji Heteroskedastisitas, dan Uji Autokorelasi menunjukkan hasil yang menyatakan bahwa data layak dilanjutkan ke dalam model regresi. Pengaruh variabel metode garis lurus, metode FIFO, Deffered tax expense dan Firm size pada Tingkat Agresivitas Wajib Pajak Badan akan ditinjau terlebih dahulu mengenai deskripsi variabel penelitian dengan analisis statistik deskriptif. Statistik deskriptif memberikan gambaran suatu data yang dapat dilihat dari nilai rata-rata (mean), standar deviasi, nilai maksimum dan nilai minimum. Hasil analisis deskriptif selanjutnya dapat dilihat pada Tabel 3.

Berdasarkan hasil pengolahan Tabel 3 menunjukan statistik deskriptif masingmasing variabel penelitian. Variabel terikat Tax Aggressiveness ( ETR ) dari penelitian ini terlihat data pada tabel di atas, menunjukkan bahwa dari 50 perusahaan yang diteliti dengan data sebanyak 250 observasi periode 2010 - 2014, diperoleh nilai rata-rata 0,2479 nilai terkecil 0,1271, nilai tertinggi 0,3566 dan stardar deviasi 0,0394. Dapat diketahui dari data diatas nilai ETR yang tinggi mengindikasikan bahwa tingkat penghindaran pajak 
menurun, artinya maka semakin tinggi nilai ETR mengambarkan bahwa perusahaan semakin tidak aggressive, jika banyak perusahaan-perusahaan tidak aggressive maka penurunan tarif tunggal pada tahun 2010 telah berhasil menekan angka penghidaran pajak.

Tabel 3. Statistik Deskriptif

\begin{tabular}{lrrrrr}
\hline & $\mathrm{N}$ & Minimum & Maximum & \multicolumn{1}{c}{ Mean } & Std. Deviation \\
\hline ETR & 250 & .1271 & .3566 & .247990 & .0394936 \\
DTE & 250 & .0001 & .0255 & .003348 & .0035932 \\
GL & 250 & 0 & 1 & .09 & .284 \\
FIFO & 250 & 0 & 1 & .83 & .375 \\
SIZE & 250 & 25.0825 & 33.0950 & 28.350763 & 1.7221300 \\
LEV & 250 & .1041 & 2.5254 & .816389 & .5874046 \\
Valid N (listwise) & 250 & & & & \\
\hline
\end{tabular}

Variabel bebas kebijakan akuntansi (Tax Accounting Choices) yang dalam penelitian ini diwakili dengan metode penyusutan (garis lurus) dari perusahaan, sampel $\mathrm{N}$ yang berjumlah 250 selama tahun 2010 sampai dengan 2014, diukur dengan variabel dummy yaitu 0 untuk perusahaan yang menggunakan metode garis lurus sedangkan nilai 1 untuk selain dari metode garis lurus. Variabel dummy juga dilakukan untuk variabel penilaian persediaan, 0 jika perusahan menggunakan metode penilaian persediaan FIFO sedangkan nilai 1 untuk selain dari metode FIFO. Data deskriptif diatas diperoleh nilai rata-rata 0,09 untuk garis lurus dan 0,83 untuk penilaian inventory, kedua variabel ini dummy jadi sudah tentu nilai minimum dan maximum nya jelas 0 dan 1 sedangkan untuk standar deviasi 0,284 pada garis lurus dan 0,375 untuk FIFO. Diketahui bahwa jika kebijakan akuntasi untuk penyusutan dan penilaian inventory bernilai 0 , maka nilai ETR akan tinggi begitu sebalik nya jika penyusutan dan penilaian inventory bernilai 1 maka nilai ETR akan rendah, ini artinya metode penyusutan dan penilaian inventory dapat dijadikan indikator perusahaan melakukan Tax Aggresiveness.

Variabel bebas Deffered tax expense dalam penelitian ini nilai minimum DTE adalah 0.0001 dan nilai maksimum 0,0255, nilai rata-rata 0,00334 dan deviasi standar 0,00359. Melihat nilai rata-rata DTE yang relatif kecil jika dibandingkan dengan nilai rata-rata ETR maka mengindiksikan bahwa alokasi pajak tangguhan yang dilaporkan semakin tinggi sehingga bisa dikatakan nilai ETR nya semakin tinggi.

Variabel bebas Firm Size berdasarkan data pada Tabel 3 di atas, dapat diketahui bahwa nilai rata-rata ukuran perusahaan (Size) 28,350 Nilai minimum 25,082 dan nilai maksimum sebesar 33.085. Melihat nilai rata-rata ukuran perusahan yang tidak terlalu jauh perbedaan nya dengan nilai minim maka dapat dikatakan bahwa perusahaan melakukan tindakan aggressive pajak namun tidak melihat besar kecilnya perusahaan.

Variabel Control Leverage merupakan variabel yang ikut mempengaruhi hubungan antara variabel bebas dengan variabel terikat, dalam penelitian ini leverage merupakan rasio total utang terhadap total Ekuitas perusahaan pada akhir tahun. Nilai rata-rata 0.8163 , nilai maksimum sebesar 2.5254 dan nilai minimum sebesar 0.1041 . Mellihat nilai rata-rata Leverage yang hampir $81 \%$ maka dapat dikatakan bahwa perusahaan dalam sampel memiliki tingkat hutang yang tinggi. 
Hasil Pengujian Data. Berdasarkan hasil pengujian yang dilakukan dengan menggunakan regresi berganda.

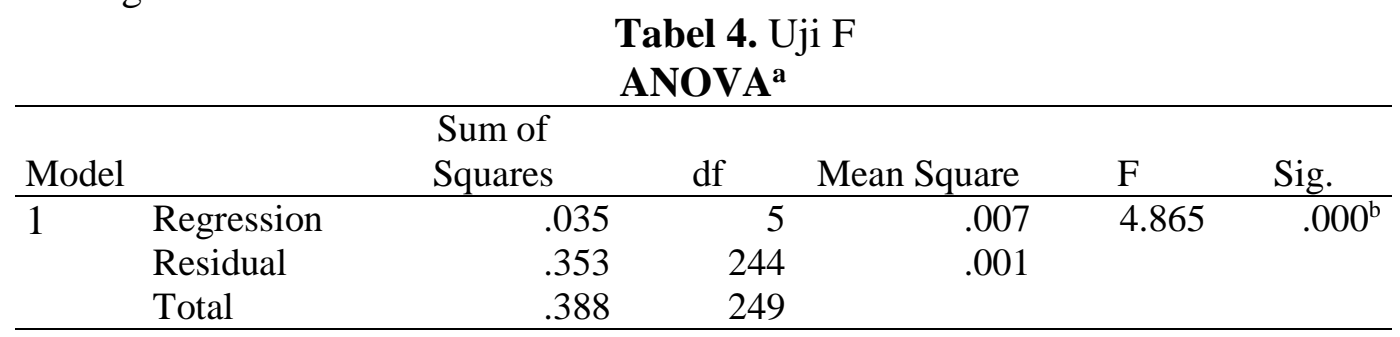

a. Dependent Variable: ETR

b. Predictors: (Constant), LEV, DTE, SIZE, FIFO, GL

Tabel 4 menunjukkan bahwa hasil uji F, nilai $\mathrm{F}$ hitung sebesar 4.865 dan $\mathrm{F}$ tabel sebesar 4,032 dengan tingkat signifikansi 0,000 dibawah 0.05, maka $F_{\text {hitung }}(4,865)>F_{\text {tabel }}(4,032)$ maka $\mathrm{H}_{1}, \mathrm{H}_{2}, \mathrm{H}_{3}$ diterima, berarti menunjukan bahwa Tax accounting choices dalam hal ini Garis lurus dan FIFO, DTE, size, Leverage secara bersama-sama signifikan berpengaruh terhadap Tax Aggressive.

Tabel 5. Hasil Uji T

\begin{tabular}{|c|c|c|c|c|c|c|}
\hline & \multirow[b]{2}{*}{ Model } & \multicolumn{2}{|c|}{$\begin{array}{l}\text { Unstandardized } \\
\text { Coefficients }\end{array}$} & \multirow{2}{*}{$\begin{array}{c}\text { Standardized } \\
\text { Coefficients } \\
\text { Beta }\end{array}$} & \multirow[b]{2}{*}{$\mathrm{t}$} & \multirow[b]{2}{*}{ Sig. } \\
\hline & & $\mathrm{B}$ & Std. Error & & & \\
\hline \multirow[t]{6}{*}{1} & (Constant) & .336 & .041 & & 8.141 & .000 \\
\hline & DTE & -2.567 & .686 & -.233 & -3.743 & .000 \\
\hline & GL & -.025 & .009 & -.178 & -2.748 & .006 \\
\hline & FIFO & -.006 & .007 & -.054 & -.870 & .385 \\
\hline & SIZE & -.003 & .001 & -.116 & -1.845 & .022 \\
\hline & LEV & .003 & .004 & .051 & .796 & .427 \\
\hline
\end{tabular}

Berdasarkan hasil perhitungan secara terpisah dengan uji t, dapat dilihat bahwa terdapat tiga variabel independen, yaitu GL,DTE, Firm Size yang berpengaruh secara signifikan terhadap variabel dependent yaitu Tax Aggressive. Berdasarkan hasil perhitungan yang ditunjukkan pada Tabel 5.

1. DTE memiliki thitung $-3,743<t_{\text {tabel }} 1.969$ dapat dikatakan bahwa variabel DTE tidak berpengaruh terhadap Tax Aggrssive, namun memiliki nilai signifikansi 0,000 < dari nilai probabilitas 0,05 maka DTE dikatakan signifikan terhadap Tax Aggressive. namun melihat koefisien dan memiliki nilai negatif yang artinya jika nilai DTE naik 1\% maka akan menurunkan nilai ETR, penurunan nilai ETR mengindikasikan kenaikan tingkat Tax Aggressive.

2. GL memiliki thitung $-0,2748<t_{\text {tabel }} 1.969$ dapat dikatakan bahwa GL tidak berpengaruh terhadap Tax Aggressive, namun melihat nilai koefisien signifikansi 0,006 < dari nilai probabilitas 0,05 maka dapat disimpulkan bahwa variabel GL memiliki pengaruh terhadap Tax Aggressive dan memiliki nilai negatif berarti jika penerapan Metode penyusutan selain garis lurus akan menurunkan nilai ETR, penurunan nilai ETR mengindikasikan peningkatan Tax Aggressive.

3. FIFO memiliki nilai signifikansi $0,385>$ dari nilai probabilitas 0,05 dan melihat thitung $0,870<t_{\text {tabel }}$ 1,969 dapat disimpulkan bahwa variabel tidak pengaruh terhadap Tax 
Aggressive, ini menandakan penerapan metode penialain persediaan dengan FIFO tidak bisa dijadikan sebagai indikator Tax Aggressive.

4. Ukuran perusahaan (SIZE) memiliki nilai thitung sebagai berikut: Variabel ukuran perusahaan (SIZE) memiliki nila thitung $-1,845<t_{\text {tabel }} 1.969$ dengan nilai signifikansi $(\alpha)$ sebesar $0,022<0,05$, berarti ukuran perusahaan (SIZE) berpengaruh terhadap Tax Aggressive. Namun nilai koefisiennya negatif artinya kenaikan size $1 \%$ belum tentu diikuti dengan kenaikan nilai ETR yang mengindikasikan penurunan Tax Aggressive.

5. Variabel control Leverage sebesar thitung $0.796<t_{\text {tabel }} 1.969$ namun dengan nilai signifikansi $(\alpha)$ sebesar $0,427>0,05$, berarti leverage tidak berpengaruh terhadap ETR. Tanda positif pada koefisien regresi tersebut menunjukkan bahwa setiap peningkatan leverage maka mengakibatkan kenaikan ETR.

Analisis regresi linier berganda merupakan hubungan antara beberapa variabel independen dengan satu variabel dependen. Hal ini untuk mengatahui arah hubungan antara variabel independen dengan variabel dependen apakah positif atau negatif dan untuk memprediksi nilai dari variabel dependen apabila nilai independen mengalami kenaikan atau penurunan. hasil seperti tabel 5 diatas dapat dilihat persamaan regresi nya sebagai berikut:

\section{TAG =0. $336-2,567 D T E-0,025 G L-0,006 F I F O-0,003 S I Z E+0,003 L E V+e$}

Pembahasan. Koefisien yang terdapat dalam model regresi menunjukan hasil hipotesis yang diajukan dalam penelitian ini menyatakan bahwa Tax Accounting Choices dalam penelitian memilih metode penyusutan garis lurus yang diukur dengan variabel dummy metode yang dipilih perusahaan berpengaruh negatif terhadap agresivitas pajak. Jika semakin tinggi pemilihan metode penyusutan garis lurus maka akan semakin tinggi laba yang dihasilkan, dengan begitu nilai ETR semakin tinggi yang mengindikasikan tingkat aggresivitas pajak menurun. Hasil pengujian seperti telah dipaparkan pada Tabel 5 diatas. Hal ini memberikan dampak bahwa pemilihan metode penyusutan selain garis lurus akan mengindikasikan peningkatan tindakan aggressive pajak. sehingga dapat dikatakan metode garis lurus dapat dijadikan indikator Tax Aggressive. Jadi kesimpulannya H1 diterima karena GL (garis lurus) berpengaruh negatif terhadap agresivitas pajak.

Variabel Tax accounting choices yang diwakili dengan metode penilaian persediaan FIFO memiliki tingkat signifikansi lebih besar dari tingkat signifikansi standar yang digunakan dalam penelitian ini. Hal ini berarti tidak berpengaruh dengan ETR sehingga tidak bisa dijadikan sebagai indikator agresivitas pajak. Hasil ini tidak sejalan dengan penelitian Golapakrishnann (1994) yang menunjukan perusahaan cenderung untuk memilih metode persediaan untuk meningkatkan laba. Laba meningkat mengindikasikan perusahaan tidak melakukan Tax Aggressive. Hasil penelitian ini sesuai dengan teori-teori agresivitas pajak, dimana Agresivitas pajak menimbulkan biaya non-pajak khususnya potensi price discount oleh pemegang saham eksternal atau minoritas. Namun manfaat yang diperoleh penghindaran pajak juga besar, dengan menghindari pajak, perusahaan dapat menghemat beban pajak sehingga perusahaan dapat mempertahankan kas yang tersedia dan menggunakannya untuk aktivitas yang lebih menguntungkan (Chen et al., 2010).

Dalam Positive accounting theory menyatakan motivasi yang mendorong manajemen untuk memilih suatu metode akuntansi tertentu sangat dipengaruhi oleh prilaku menejer (Desai et al, 2002; Kothari, S.P, (2001). Dengan semakin berkembangnya organisasi, semakin jauh jarak antara manajemen (principal) dengan pihak yang 
mempercayakan uangnya agent (Suzuki, 2003 dan Meland, 2002). Agent akan mendapatkan insentif dari prinsipal sesuai dengan kinerja yang dicapainya yang disampaikan melalui informasi akuntansi perusahaan.

Hasil koefisien regresi pada tabel 5 menunjukkan bahwa DTE mempunyai pengaruh yang signifikan negatif terhadap Aggresivitas pajak, dengan kata lain $\mathrm{H}_{2}$ dalam penelitian ini diterima . Hal ini mengindikasikan bahwa besarnya DTE perusahaan berpengaruh signifikan terhadap Aggresivitas Pajak. Hassan (2012) mengutip Dhaliwal dan Wang (1992) melaporkan bukti bahwa perusahaan melakukan penyesuain angka-angka akuntansi dengan menggeser perbedaan tetap dan perbedaan waktu pada beberapa periode untuk meminimalkan dampak pajak.

Berdasarkan PSAK no. 46 alokasi pajak antar periode diawali dengan adanya keharusan bagi perusahaan untuk mengakui aktiva dan kewajiban pajak tangguhan yang harus di laporkan dineraca. Pengakuan aktiva dan kewajiban pajak tangguhan tersebut merupakan pengakuan tentang konsekuensi pajak dimasa mendatang atas efek kumulatif perbedaan temporer pengakuan penghasilan dan beban untuk tujuan akuntansi dan tujuan fiskal. Dalam pendekatan aktiva-kewajiban, yang dimaksud dengan perbedaan temporer adalah perbedaan antara dasar pengenaan pajak (DPP) dari suatu aktiva atau kewajiban dengan nilai tercatat aktiva atau kewajiban tersebut. Efek perubahan perubahan temporer yang terefleksi pada kenaikan atau penurunan aktiva dan kewajiban pajak tangguhan harus diperlakukan sebagai beban pajak tangguhan (deferred tax expenses) atau penghasilan pajak tangguhan (deferred tax income) dan dilaporkan dalam laporan laba-rugi tahun berjalan bersama-sama beban pajak kini (current tax expenses), dengan penyajian secara terpisah.

Hasil penelitian ini sesuai dengan Suandy (2008) dan Meiza (2013) mengungkapkan bahwa apabila pada masa mendatang akan terjadi pembayaran yang lebih besar, maka berdasarkan SAK harus diakui sebagai suatu kewajiban. Sebagai contoh apabila beban penyusutan aset tetap yang diakui secara fiskal lebih besar daripada beban penyusutan aset tetap yang diakui secara komersial sebagai akibat adanya perbedaan metode penyusutan aktiva (aset) tetap, maka selisih tersebut akan mengakibatkan pengakuan beban pajak yang lebih besar secara komersial pada masa yang akan datang. beban pajak ditunda perusahaan yang diukur dengan alokasi pajak antar periode akan mempengaruhi penghindaran pajak perusahaan, semakin tinggi alokasi antar periode berarti semakin kecil praktik tax avoidance yang dilakukan perusahaan. Plesko (2002) dan Phillips (2003) mengungkapkan bahwa semakin besar perbedaan antara laba fiskal dengan laba akuntansi menunjukkan semakin besarnya diskresi manajemen. Besarnya diskresi manajemen tersebut akan terefleksikan dalam beban pajak tangguhan dan mampu digunakan untuk mendeteksi praktik Tax Aggressive pada perusahaan.

Firm Size merupakan nilai yang menunjukkan besar kecilnya perusahaan. Ukuran yang biasa digunakan untuk mewakili ukuran perusahaan diantaranya yaitu total penjualan, total asset, dan kapitalisasi pasar. Semakin besar nilai total penjualan, total asset, dan kapitalisasi pasar maka semakin besar ukuran perusahaan. Penelitian ini menggunakan logaritma natural dari total asset perusahaan. Penggunaan total asset dalam penelitian ini berdasarkan pada alasan bahwa total asset merupakan ukuran yang relatif stabil dibandingkan dengan ukuran lain dalam mengukur ukuran perusahaan Hendy Darmawan dan Sukartha (2014).

Hasil pengujian Firm Size berpengaruh negatif terhadap agresivitas pajak. Semakin besar ukuran perusahaan maka perusahaan ETR akan meningkat dan tax aggressive akan 
menurun. Demikian juga halnya dengan fenomena yang terjadi di Indonesia di Indonesia saat ini,reformasi pajak yang dilakukan dengan penerapan tariff tunggal sejak tahun 2010 berdampak pada penerimaan Negara yang semakin naik dari tahun ke tahun. Hal ini menunjukkan bahwa kesadaran akan pentingnya pajak dalam pembiayaan pembangunan telah merubah prilaku dari wajib pajak. Berdasarkan hasil penelitian ini dapat ditarik suatu kesimpulan bahwa perusahaan yang memiliki asset yang besar belum tentu malakukan penghindaran pajak atau melakukan tax aggressive. Hal ini menunjukkan reformasi pajak yang dilakukan oleh pemerintah baik dari sisi administrasi dan perbaikan system informasi dan teknologi dan sanksi pajak, yang terkait dengan system penyetoran dan pemungutan pajak, telah mampu meningkatkan penerimaan Negara. Hasil ini menunjukkan bahwa ukuran perusahaan yang besar yang sebenar memiliki dana cukup besar untuk dapat membiayai perihal perpajakannya secara khusus oleh profesional seperti konsultan pajak yang mengetahui peraturan pajak secara rinci, belum tentu melakukan penghindaran pajak atau melakukan tax aggressive (Rusdi, 2013) .

Hasil penelitian ini bertentangan dengan hasil penelitian sebelumnya yang menunjukkan hubungan positif antara ukuran perusahaan dengan tax aggressive (Rego,2003; Hanlon, 2005; Derashid et al, 2003; Kim dan Limpaphayom, 1998), mereka menyimpulkan bahwa semakin besar perusahaan maka efektif tax rate (ETR) semakin kecil, data tersebut menunjukkan semakin meningkatnya tindakan aggressive tax avoidance. Hal ini juga sejalan dengan penelitian Hendy Darmawan dan Sukartha (2014) ukuran perusahaan berpengaruh pada penghindaran pajak. Namun dalam praktiknya, penghindaran pajak dapat memberikan efek yang negatif bagi perusahaan. Chen et al (2013) menyatakan praktik penghindaran pajak memerlukan biaya yang tidak sedikit, beberapa biaya yang akan berpotensi muncul yang sering disebut dengan agency cost.

Perusahaan yang mempunyai tingkat leverage tinggi berarti sangat bergantung pada pinjaman luar untuk membiayai asetnya. Sedangkan perusahaan yang mempunyai tingkat leverage rendah, berarti perusahaan tersebut lebih banyak membiayai asetnya dengan modal sendiri. Perusahaan yang memiliki kemungkinan lebih tinggi dalam melanggar perjanjian utang cenderung terlibat dalam praktik agresivitas pajak untuk meningkatkan laba perusahaan.

Teori Akuntansi Positif dengan Hipotesis debt covenant menjelaskan semakin tingginya hubungan perusahaan dengan pihak ketiga (kreditur) maka perusahaan akan lebih menjaga laba periode berjalan dengan tujuan untuk menjaga stabilitas kinerja perusahaan yang dijelaskan melalui laba karena semakin tingginya kepentingan perusahaan dengan kreditur maka kreditur akan lebih mengawasi perusahaan dengan alasan kelangsungan pinjaman modal eksternal. Perusahaan dengan tingkat Leverage yang tinggi tidak akan agresif dalam hal perpajakan karena perusahaaan harus mempertahankan laba mereka karena terikat dengan kepentingan kreditur. Apabila perusahaan berusaha meningkatkan laba, maka beban pajak yang dibayarkan juga akan meningkat (Watts dan Zimmerman, 1986).

\section{PENUTUP}

Simpulan. Berdasarkan hasil penelitian yang telah diuraikan di atas, maka kesimpulan dari penelitian Tax Accouting choices untuk Metode Garis lurus yang diukur menggunakan variabel dummy berpengaruh positif terhadap ETR atau bisa dikatakan tingkat Agresivitas Pajaknya menurun, hal ini mengindikasikan metode garis lurus sebagai 
indikator Tax Aggressiveness. Berbeda dengan Metode Penilaian persediaan yang diukur menggunakan variabel dummy, hasilnya tidak berpengaruh artinya metode penilaian persediaan FIFO tidak dapat dijadikan indikator Tax Aggressiveness, artinya tindakan agresivitas pajak tidak melihat kebijakan metode penilaian persediaan yang diterapkan.

Deffered tax expense berpengaruh negatif terhadap Agresivitas Pajak. Temuan penelitian ini mendukung hipotesis yang diajukan. Tingkat alokasi beban pajak tanggguhan antar periode semakin tinggi, maka akan menurunkan nilai ETR, ini menandakan semakin meningkatnya agresivitas pajak. Transaksi akuntansi yang mengakibatkan perbedaan temporer ini antara perlakuan akuntansi dan perpajakan yang merupakan unsur Pajak Tangguhan diantaranya adalah perbedaan metode penyusutan antara akuntansi dengan pajak, karena perbedaan temporer yang sering kali digunakan perusahaan untuk merencanakan pajak sedangkan untuk Firm Size berpengaruh negatif terhadap Tax Aggressiveness, artinya hasil penelitian ini mendukung hipotesis yang diajukan, bahwa semakin besar ukuran perusahaan maka semakin aggressive ditunjukkan dengan nilai ETR yang semakin menurun.

Implikasi Penelitian. Pemerintah sebagai regulator dan lembaga profesi harus lebih fokus dalam pemilihan kebijakan akuntansi yang diterapkan dalam pelaporan keuangan, sehingga meminimalkan tindakan aggressive. Pemerintah perlu harus lebih menganalisa tingkat penerimaan pajak dengan membandingkan tarif effective tax rate yang berjalan setiap tahun atau jika terjadi penurunan tarif apa mampu mencapai target pernerimaan pajak.Disamping tariff pemerintah juga harus terus melakukan reformasi perpajakan dengan membuat infrastruktur baik peraturan maupun system informasi yang terus member kemudahan bagi wajib pajak, sehingga berdampak pada meningkatnya jumlah wajib pajak dan juga berdampak kepada kepatuhan wajib pajak dalam memenuhi kewajiban pajaknya.

Saran. Berdasarkan kesimpulan di atas, saran dan rekomendasi yang dapat disampaikan adalah sebagai berikut: (1) Mengembangkan pengukuran lain untuk Tax accounting choices dalam hal ini metode penyusutan garis lurus dan penilaian persediaan dengan ukuran rasio tidak dengan variabel dummy;(2) Untuk regulator dan standard setter harus lebih konsen dalam pemilihan kebijakan akuntansi yang diterapkan dalam pelaporan keuangan, sehingga meminimalkan tindakan aggressive; (3) Pemerintah perlu harus lebih menganalisa tingkat penerimaan pajak dengan membandingkan tarif effective tax rate yang berjalan setiap tahun atau jika terjadi penurunan tarif apa mampu mencapai target pernerimaan pajak.

\section{DAFTAR RUJUKAN}

Andreoni, James, Brian Erard and Jonathan Feinstein (1998) “Tax compliance”, Journal of Economic Literature 36(2): 818-60.

Bushman and William (2013) Governance, Competition and Opportunistic Accounting Choices by Banks, University of Michigan.

Barnes, Paul dan HD. Huan. (1993. "The Auditors Going Concern Decision : Some UK Evidence Concerning Independence and Competence”. Journal of Business, Finance \& Accounting 20(2): 213-228.

Brigham F. Eugene dan Houston, Joel. (2010) Dasar-Dasar Manajemen Keuangan: Assetials Of Financial Management. Jakarta: Penerbit Salemba Empat. 
Balakrishnan Blouin And Guay (2011) Does Tax Aggressiveness ReduceFinancialReporting Transparency?, University of Pennsylvania.

Chen, Shuping et al. (2010) "Are Family Firms more Tax Aggressive than Non-family Firms?”, Journal of Financial Economics, 95: 41-61

Chen, K. P dan Chu, C. Y. C. (2010) "Internal Control vs ExternalManipultion: A Model ofCourporate Income Tax Evasion”. Rand Journal of Economics.

Chen, K. H., Mo, P. L. L. \& Zhou, A. Y. (2013) "Government ownership, corporate governance and tax aggressiveness: evidence from China”. Accounting \& Finance, 53, 1029-1051.

Christie, A., Zimmerman, J.,(1994) "Efficient and opportunistic choices of accounting procedures". The Accounting Review, 69: 539-567.

Collins, D., E. Maydew, and I. Weiss. (1997) "Changes in the Value-Relevance of Earnings and Book Values over the Past Forty Years”. Journal of Accounting and Economics, 24 (1): 39-67.

Desai M. A., and D. Dharmapala, (2006) "Corporate tax avoidance and high-powered incentives”. Journal of Financial Economics 79: 145-179.

Desai, M., and Dharmapala, D., (2008) "Corporate Tax Avoidance and HighpoweredIncentives”. Journal of Financial Economics, 84: 591-623.

Derashid, C, dan H. Zhang., (2003) "Effective tax rates and the "industrial Policy hypotesis: evidence from Malaysia". Journal of International Accounting \& Taxation, 12: 45-62.

Dijke, Marius van and Peter Verboon (2010) "Trust in authorities as a boundary condition to procedural fairness effects on tax compliance", Journal of Economic Psychology 31: 80-91.

Dyreng, S., M.Hanlon., dan E.L.Maydew. (2008) “Long run corporate tax avoidance”. The Accounting Review, 83: 61-82.

Frank, M. M., Lynch, L. J., \& Rego, S. O. (2009) “Tax Reporting Aggressiveness and Its Relation to Aggressive Financial Reporting'. The Accounting Review. Vol. 84: 467496.

Gopalakrishnan (1994) 'Accounting Choice Decisions and unlevered firm: Futher evidence on Debt /Equity Hypothesis', Journal Of Financial And Strategic Decisions, George Mason University.

Harta Dinata dan Shauki, Elvia.. (2012) “Agency, Leverage policy and Tax Aggressiveness". Journal of Accounting.Universitas Airlangga dan University of south Australia.

Hanlon, H.S. (2010) “A Review of Tax Research”. Journal of Accounting and Economics, 50:127-178.

Hanlon, M. (2005) "The Persistence and Pricing of Earnings, Accruals, and Cash Flows When Firms Have Book-Tax Differences”. The Accounting Review, 80(1): 137-166.

Hendy Darmawan dan Sukartha, (2014) "Pengaruh Penerapan Corporate Governance, Leverage, Return On Assets, dan Ukuran Perusahaan pada Penghindaran pajak”, EJurnal Akuntansi Universitas Udayana. 9(1): 143-161.

Horne, James C.V and Wachoviz Jr, John M. (1998) Fundamental of Financial Management. 8th ed. Prentice Hall International. New Jersey

Ida Bagus Putu Fajar Adisamartha dan Naniek Noviari, (2015) "Pengaruh likuiditas, leverage, intensitas persediaan dan intensitas asset tetap pada tingkat agresivitas pajak”, E-Jurnal Akuntansi Universitas Udayana.13(3): 973-1000. 
Imam Ghozali. (2011) Aplikasi Analisis Multivariate dengan ProgramSPSS, edisi 5, Badan Penerbit Universitas Diponegoro, Semarang.

Ikatan Akuntansi Indonesia. 2009. ED PSAK No. 01 (Revisi 2009). Salemba Empat. Jakarta.

Jensen, Michael C., and Meckling, William H. (1976)“Theory of the Firm: Managerial Behavior, Agency Costs and Ownership Structure”. Journal of Financial Economics, 3(4): 305-360.

Kasipillai, J. and Mahenthiran, S., (2013) "Deferred taxes, earnings management, andcorporate governance: Malaysian Evidence”. Journal of Contemporary Accounting \&Economics, 9: 1-18

Kieso, Weygandt, dan Warfield. (2010) Akuntansi Intermediate, Edisi Kedua Belas, Erlangga, Jakarta.

Khoiru Rusydi M.. (2009) "Dampak Persepsi Tanggung Jawab Sosial Perusahaan Terhadap Manajemen Perpajakakan (Tax Planning)”. Jurnal Akuntansi dan Bisnis, 9 (1): 67-85

Kothari, S.P., Leone, A.J., \& Wasley, C.E. (2005) "Performance Matched Discretionary Accrual Measures”. Journal of Accounting and Economics, 39 (1): 163-197.

Lanis, R. and G. Richardson. (2012) "Corporate Social Responsibility and Tax Aggressiveness: An Empirical Analysis”. J. Account. Public Policy, pp.86-108.

Lanis, R. and G. Richardson. (2013) "Corporate Social Responsibility and Tax Aggressiveness: a test of legitimacy theory'. Accounting Auditing and Accountability Journal, 26 (1): 75 - 100.

Martani,D., dan A.E.Persada. (2009) Pengaruh Book Tax Gap Terhadappersistensilaba. Jurnal Akuntansi Universitas Indonesia. Jakarta.

Mardiasmo. (2009) Perpajakan Edisi Revisi. Yogyakarta: Penerbit Andi, 2009.

Meiza, (2013) 'Pengaruh Karekterik Good Corporate GovernancedanDeffered tax expense terhadap Tax Avoidance', Jurnal Universitas Padang.

Muhammad Aminu Isa (2014) International Conference on Accounting Studies 2014, ICAS 2014, 18-19 August 2014, KualaLumpur, MalaysiaUniversity Malaysia Utara.

Nora Sabrina Sirait dan Dwi Martani (2014) "Pengaruh Book Tax Deffered dan kepemilikan keluarga terhadap Tax Avoidance'. Jurnal Akuntansi Universitas Indinesia. Jakarta.

OECD. (2001) Tax Ratios: A Critical Survey. The Policy Studies. Paris: Perancis.

Organization for Economic Coperation and Development (OECD). (2004) The OECD Principles of Corporate Governance. (http://www.oecd.org).

Prianto, Budi (2012) Konfergensi IFRS dan Pengaruhnya tehadap Pajak, Jakarta.

Philips, J., M. Pincus, and S. Rego. (2003) "Earnings Management: New Evidence Based on Deferred Tax Expense”. The Accounting Review, 78(2): 491-521.

Plesko, A.George (2002) "Corporate Tax Avoidance and the Properties of Corporate Earnings”, National Tax Journal, LVII (3): 729-737.

Rego, S.O. (2003) “Tax-avoidance Activities of U.S. Multinational Firms”. Contemporary Accounting Research, 20(4): 805-833.

Rego, S. O., and R. Wilson, (2012) "Equity risk incentives and corporate tax aggressiveness". Journal of Accounting Research 50: 775-810.

Riahi-Belkaoui, Ahmed. (2011) Teori Akuntansi. Jakarta: Salemba Empat. 
Richardson, G., \& Lanis, R. (2007) "Determinants of the variability in corporate effective tax rates and tax reform: Evidence from Australia”. Journal of Accounting and Public Policy, 26(6): 689-704.

Richardson, Grant and Roman Lanis. (2012) "Corporate Social Responsibility and Tax Aggressiveness”. Journal of Accounting Public Policy. Australia.

Sabrina Sirait, dan Dwi Martani., (2014) "Pengaruh perusahaan keluarga terhadap Penghindaran Pajak pada perusahaan manufaktur di Indonesia dan Malaysia”. Jurnal Universitas Mataram, SNA 17 Lombok.

Scott, William R. (2014) Financial Accounting Theory. Second edition. Canada: Prentice Hall.

Sekaran, Uma dan Roger Bougie. (2011) Research Methods for Business a Skill Building Approach.5th edition. UK: John Wiley \& Sons Ltd.

Siegfried, J. (1972) "The Relationship between Economic Structure and the Effect of Political Influence: Empirical Evidence from the Federal Corporation Income Tax Program.” PhD Dissertation, University of Wisconsin.

Watts, R, L., and Zimmerman, J, L. (1986) Positive Accounting Theory. New York, Prentice Hall.

Yin, Jennifer, and Agnes Cheng. (2004) "Earnings Management of Profit Firms and Loss Firms in Response to Tax Rate Reductions". Review of Accounting and Finance volume 3: $67-92$.

Uadiale, O. M., T.O. Fagbemi and J.O. Ogunleye (2010) “An Empirical Study of the Relationship between Culture and Personal Income Tax Evasion in Nigeria”. European Journal of Economics, Finance and Administrative Sciences, 20: 116-126.

Zeff, Stephen A. (1978) "The Rise Of Economic Consequences". The Journal Of Accountancy, Desember: 56-63

Zimmerman, JL. (1983) "Taxes and Firm Size.” Journal of Accounting and Economics, 5: 49-119 